\title{
Overexpression of CREM $\alpha$ lpha accelerates onset and severity of auto-immune mediated disease in a murine model of lupus
}

\author{
Kim Ohl ${ }^{1 *}$, Ralph Lippe ${ }^{2}$, Eva Verjans ${ }^{1}$, Nora Honke ${ }^{1}$, Karin Maschke-Neuss ${ }^{1}$, Norbert Wagner $^{1}$, Johannes Roth², \\ Klaus Tenbrock ${ }^{1}$
}

From 18th Pediatric Rheumatology European Society (PReS) Congress

Bruges, Belgium. 14-18 September 2011

The transcription factor cAMP response element modulator (CREM) is a widely expressed transcriptional repressor which is important for the termination of the $\mathrm{T}$ cell immune response. CREM $\alpha$ is overexpressed in SLE (Systemic lupus erythematosus) T cells and is supposed to be a key player in orchestrating the transcriptional program of SLE $\mathrm{T}$ cells by targeting $\mathrm{T}$ cellrelevant genes. To explore the relevance of CREM $\alpha$ in vivo we used a well-established murine lupus model, which is characterized by the introduction of a mutation in the CD95 (Fas) locus. We generated a transgenic mouse with a selective overexpression of CREM $\alpha$ in $\mathrm{T}$ cells and introduced a Fas -/- phenotype into the CREM $\alpha$ transgenic mice. CREM $\alpha$ transgenic Fas -/mice developed a severe lymphadenopathy and splenomegaly as early as 8 weeks of age, while the wildytpe Fas -/- mice did not at this early age. Lymphadenopathy and splenomegaly is paralleled by a massive expansion of pathogenic CD3+CD4-CD8- double negative T cells. Furthermore $\mathrm{T}$ cells of CREM $\alpha$ transgenic Fas -/- mice show an enhanced production of IL-21 and IL-17, which are hallmark cytokines of highly inflammatory Th17 cells. Vice versa percentages of regulatory $\mathrm{T}$ cells are reduced. The enhanced occurrence of aberrant and inflammatory $\mathrm{T}$ cells further leads to increased $\mathrm{B}$ cell activation, increased anti-DNA antibody titers and finally shortened life expectation of these mice.

Our experiments are the proof of principle for a critical amplifying role of CREM $\alpha$ in autoimmune prone conditions like SLE.

\footnotetext{
* Correspondence: kohl@ukaachen.de

${ }^{1}$ Klinik für Kinder und Jugendmedizin, Klinikum der RWTH Aachen, Germany
} Full list of author information is available at the end of the article

\section{Author details}

${ }^{1}$ Klinik für Kinder und Jugendmedizin, Klinikum der RWTH Aachen, Germany. ${ }^{2}$ Institut für Immunologie, Universität Münster, Germany.

Published: 14 September 2011

doi:10.1186/1546-0096-9-S1-03

Cite this article as: Ohl et al:: Overexpression of CREM $\alpha$ lpha accelerates onset and severity of auto-immune mediated disease in a murine model of lupus. Pediatric Rheumatology 2011 9(Suppl 1):03.

\section{Submit your next manuscript to BioMed Central and take full advantage of: \\ - Convenient online submission \\ - Thorough peer review \\ - No space constraints or color figure charges \\ - Immediate publication on acceptance \\ - Inclusion in PubMed, CAS, Scopus and Google Scholar \\ - Research which is freely available for redistribution \\ Submit your manuscript at www.biomedcentral.com/submit}

